\title{
Control over [2+2+2] and Carbonylative [4+2] Cycloaddition by CO Pressure in Co-Catalyzed Cycloaddition between Internal Diynes and Cyclopentadiene
}

\author{
Do Han Kim, Young Keun Chung," and Jin Wook Han** \\ Intelligent Textile System Research Center, and Department of Chemistry, College of Katural Sciences, Seoul Kational Lniversity, \\ Seoul 151-747, Korea. "E-mail: Wchmgasmac.kr \\ ${ }^{\dagger}$ Department of Chemistry, Hamang Lniversity, Seoul 133-791, Korea. *E-mail: jwantahatnang.ac.kr \\ Received Harch 18, 2008
}

\begin{abstract}
The reaction of internal diynes and cyclopentadiene in the presence of $5 \mathrm{~mol} \%$ of cobalt catalysts proceeded under $5 \mathrm{~atm}$ of carbon monoxide pressure to give a high yield of the corresponding [2+2+2] cycloaddition product. By lowering carbon monoxide pressure from 30 atm to $5 \mathrm{~atm}$. cyclopentadiene can be used as a dienophile in the cobalt carbonyl-catalyzed $[2+2+2]$ cycloaddition reaction between intemal diỵnes and cyclopentadiene.
\end{abstract}

Key Words : $[2+2+2]$ Cycloaddition, Diyne. Cobalt catalyst

\section{Introduction}

Cobalt-catalyzed or - mediated $[2+2+2]$ cycloaddition has been an important step in the preparation of useful organic molecules. ${ }^{\text {I: }}$ The cobalt-catalyzed cycloaddition of three unsaturated $\mathrm{C}-\mathrm{C}$ bonds with a high degree of chemo- regio-. and stereoselectivity led to the synthesis of several natural and unnatural products. ${ }^{3}$ A number of acetylenes and heterocyclic olefins have been utilized as cyclization partners. ${ }^{+}$ whereas the use of simple alkenes is uncommon in these cycloaddition reactions. "In particular. use of conjugated dienes as a dienophile in the $[2+2+2]$ cycloaddition has not been reported yet. as far as we are aware.

On our continuous efforts for synthesis of polycyclic compounds utilizing the Pauson-Khand reaction. we found that reaction pathways could be changed simply by varying $\mathrm{CO}$ pressure in the cobalt-catalyzed cycloaddition reaction of diynes in the presence of cyclopentadiene. Recently. we reported that Co-catalyzed tandem carbonylative cyclization of internal diynes in the presence of cyclopentadiene under 30 atm of $\mathrm{CO}$ pressure afforded tetracyclic enone compounds. in which reaction carbon monoxide took a part at the first step of the tandem reaction. ${ }^{6 a}$ On the other hand. we also found that only simple $[2+2+2]$ cycloadducts of an internal diyne and cyclopentadiene in a similar reaction condition under 5 atm of $\mathrm{CO}$ pressure were obtained (Figure 1). ${ }^{7}$

We decided to examine the reaction carefully focusing on the pressure of carbon monoxide and found that cyclo- pentadiene could be used as a dienophile in cobalt-catalyzed $[2+2+2]$ cycloaddition under a low pressure of $\mathrm{CO}$. Herein. we report the $\mathrm{Co}_{2}(\mathrm{CO})_{8}$-catalyzed intermolecular $[2+2+2]$ cycloaddition of internal diynes and cyclopentadiene under a low pressure of carbon monoxide.

\section{Results and Discussion}

In order to investigate the influence of CO pressure and to optimize reaction conditions. the $\mathrm{CO}$ pressure, the cobaltcatalysts. and the reaction temperature were screened for cobalt-catalyzed $[2+2+2]$ cycloaddition of bis(1-phenyl-1propynyl) ether (1a) and cyclopentadiene (Scheme 1 and Table 1).

As expected no reaction was observed without any cobalt-catalysts (entry 1 in Table 1). The $[2+2+2]$ cycloadduct $2 \mathrm{a}$ was not obtained in the presence of the wellknown catalyst. ${ }^{2} \mathrm{CpCo}(\mathrm{CO})_{2}$. either. whereas $2 \mathrm{a}$ was obtained in $75 \%$ yield without any other product in the presence of

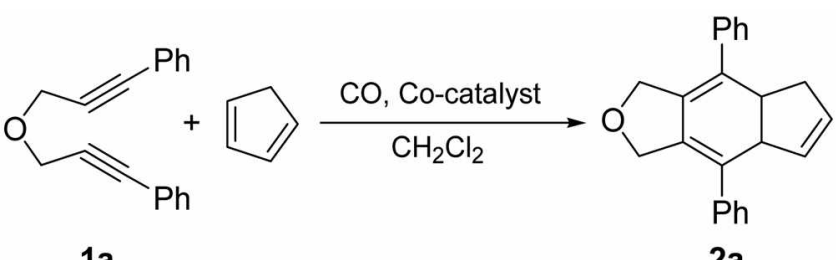

1a

Scheme 1. $[2+2+2]$ cycloaddition of intemal diyne $1 \mathrm{a}$ and cyclopentadiene.<smiles>[R]C1=C2CCC3=C([Y])C(=O)CC2(C1)C3[R]</smiles><smiles>CC(=O)OC(C)(C)C</smiles>

Carbonylative cyclization<smiles>[R]C#CCC[X]</smiles><smiles>C1=CCCC=C1</smiles>

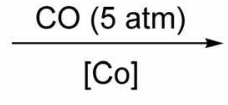
[2+2+2] cyclization<smiles>[X]C1=C2CC=CC2C([R])=C2CC=CC12</smiles>

Figure 1. Different reaction pathways attained by varying CO pressure in the Co-catalyzed cyclization of intennal diynes in the presence of cyclopentadiene. 
Table 1. $[2+2+2]$ Cycloaddition of internal diyne 1a and cyclopentadiene ${ }^{\prime \prime}$

\begin{tabular}{|c|c|c|c|c|}
\hline Entry & Catalyst & $\mathrm{CO}$ (atmin) & Temp $\left({ }^{\circ} \mathrm{C}\right)$ & Yield $(\%)^{b}$ \\
\hline 1 & - & 5 & 120 & $-^{c}$ \\
\hline 2 & $\mathrm{CpCo}(\mathrm{CO})_{2}$ & 5 & 120 & $-{ }^{c}$ \\
\hline 3 & $\mathrm{CO}_{2}\left(\mathrm{CO}_{3}\right.$ & 5 & 120 & 75 \\
\hline 4 & $\mathrm{CO}_{2}\left(\mathrm{CO}_{3}\right.$ & $-d$ & 120 & 2 \\
\hline 5 & $\mathrm{CO}_{2}\left(\mathrm{CO}_{k}\right.$ & $-{ }^{e}$ & 120 & 35 \\
\hline 6 & $\mathrm{Co}_{2}\left(\mathrm{CO}_{k}\right)_{3}$ & 2 & 120 & 49 \\
\hline 7 & $\mathrm{Co}_{2}\left(\mathrm{CO}_{k}\right.$ & 10 & 120 & $38^{\prime}$ \\
\hline 8 & $\mathrm{CO}_{2}\left(\mathrm{CO}_{3}\right.$ & 5 & 80 & 19 \\
\hline
\end{tabular}

"Reactions were carried out with 1 a $(0.8 \mathrm{mmol}) . \mathrm{CpH}(4.0 \mathrm{mmol})$ and appropriate $\mathrm{CO}$ pressure with $5 \mathrm{~mol}$ \%. of of Co-catalyst in $\mathrm{CH}_{2} \mathrm{Cl}=(30 \mathrm{~mL})$ for 18 h. "Isolated vield. No reaction. "Under 1 atm of $N_{2}$. "Under 5 atm of $\mathrm{N}_{\mathrm{s}}$. Tandem carbonylative cvelization product was obtained additionally in $19^{\circ} .6$ yield.

$\mathrm{Co}_{2}(\mathrm{CO})_{8}$ under $5 \mathrm{~atm}$ of $\mathrm{CO}$ (entries 2 and 3 in Table 1). Because carbon monoxide did not participate in the cycloaddition reaction as a cyclization partner. it was necessary to determine the importance of $\mathrm{CO}$ in the reaction. Thus. reactions were carried out under nitrogen pressure instead of $\mathrm{CO}$ pressure (entries 4 and 5 in Table 1). Under 1 atm of $\mathrm{N}$ : pressure. a stoichiometric reaction occurred to give $2 \%$ yield based on the diyne used or $40 \%$ yield based on the cobalt carbonyl used. Interestingly. the reaction under 5 atm of $\mathrm{N}$ : pressure was revealed to be a catalytic reaction giving an improved yield of $35 \%$. These results indicate that the increased nitrogen pressure may help regeneration and/or stability of catalytic species. The optimum pressure of $\mathrm{CO}$ was found to be $5 \mathrm{~atm}$ for this $[2+2+2]$ cycloaddition (entries 3, 6. and $7 \mathrm{in}$ Table 1). As $\mathrm{CO}$ pressure increased from $2 \mathrm{~atm}$ to $5 \mathrm{~atm}$. the yield increased from $49 \%$ to $75 \%$. The role of $\mathrm{CO}$ pressure in the reaction would also be related to regeneration and/or stability of the catalyst. However, a CO pressure higher than 5 atm was not beneficial to the $[2+2+2]$ cycloaddition. Under $10 \mathrm{~atm}$ of $\mathrm{CO}$ pressure a carbony lative cycloaddition product in $19 \%$ yield was obtained additionally in company with $2 a$ in $38 \%$ yield. The carbonylative cycloaddition product was characterized as the same product synthesized by the Pauson-Khand reaction and subsequent $[4+2]$ cycloaddition of $1 \mathrm{a}$ and cyclopentadiene in a tandem fashion. ${ }^{64}$ As previously reported. the tanden carbonylative cycloaddition was the main reaction pathway under $\mathrm{CO}$ pressure higher than 10 atm. ${ }^{6}$ Catalytic activity was also decreased by lowering the reaction temperature from $120^{\circ} \mathrm{C}$ to $80^{\circ} \mathrm{C}$ (entry 8 in Table 1).

These results in Table I show that reaction pathways can be changed simply by varying $\mathrm{CO}$ pressure in the cobalt carbonyl-catalyzed cycloaddition reaction of internal diyne 1a in the presence of cyclopentadiene. By lowering $\mathrm{CO}$ pressure to $5 \mathrm{~atm}$. carbon monoxide did not take part in the reaction to give the $[2+2+2]$ cycloadduct without producing the carbonylative cycloadduct of which $\mathrm{CO}$ was one of the components. It is intriguing that the pressure of $\mathrm{CO}$ in such a narrow range can be used to control the cycloaddition outcome.
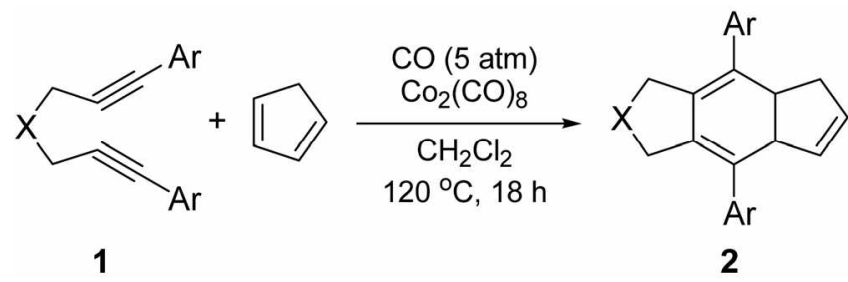

Scheme 2. $\mathrm{Co}_{2}(\mathrm{CO})$-catalyzed $[2+2+2]$ cycloaddition of intemal diynes 1 and $\mathrm{CpH}$.

Table 2. $\mathrm{CO}_{2}(\mathrm{CO})_{3}$-catalyzed $[2+2+2]$ cycloaddition of intemal diynes 1 and $\mathrm{CpH}^{2}$

\begin{tabular}{cccccc}
\hline Entry & $\mathrm{X}$ & $\mathrm{Ar}$ & Diyne & Cycloadduct & Yield $(\%)^{h}$ \\
\hline $\mathrm{I}$ & $\mathrm{O}$ & $\mathrm{Ph}$ & $\mathbf{1 a}$ & $\mathbf{2 a}$ & 75 \\
2 & $\mathrm{O}$ & $4-\mathrm{MeC}_{6} \mathrm{H}_{4}$ & $\mathbf{1 b}$ & $\mathbf{2 b}$ & 72 \\
3 & $\mathrm{O}$ & $4-\mathrm{FC}_{6} \mathrm{H}_{4}$ & $\mathbf{1 c}$ & $\mathbf{2 c}$ & 58 \\
4 & $\mathrm{TsN}$ & $\mathrm{Ph}$ & $\mathbf{1 d}$ & $\mathbf{2 d}$ & 89 \\
5 & $\mathrm{H}_{2} \mathrm{C}$ & $\mathrm{Ph}$ & $\mathbf{1 e}$ & $\mathbf{2 e}$ & 18 \\
6 & $\left(\mathrm{MeO}_{2} \mathrm{C}\right)_{2} \mathrm{C}$ & $\mathrm{Ph}$ & $\mathbf{1 f}$ & $\mathbf{2 f}$ & 89 \\
\hline
\end{tabular}

"Reactions were carried ont with $1(0.8 \mathrm{mmol}) . \mathrm{CpH}(4.0 \mathrm{mmol})$. and 5 atm of $\mathrm{CO}$ pressure with $5 \mathrm{~mol}^{\circ}{ }_{0}$ of $\mathrm{Con}_{2}\left(\mathrm{CO}_{8}\right.$ in $\mathrm{CH}_{2} \mathrm{Cl}_{2}(30 \mathrm{~mL})$ for 18 1. " Isolated yield.

Cobalt carbonyl-catalyzed $[2+2+2]$ cycloaddition between cyclopentadiene and internal diynes having various tether groups and aryl substituents at both alkyne termini were examined under the optimized reaction conditions for 1a (Scheme 2 and Table 2). ${ }^{7}$

Cobalt carbonyl-catalyzed $[2+2+2]$ cycloaddition reactions of propargyl ether derivatives having aryl groups with either electron-donating or electron-withdrawing substituents at both of alkyne termini afforded the desired product in good yields (entries $1-3$ in Table 2). For these oxygen-tethered internal diynes. the diyne with electron-1vithdrawing aryl substituents showed a lower catalytic reactivity than that with electron-donating aryl substituents. For a nitrogentethered internal diyne (1d) and a quaternary carbon-tethered diyne (1f) with phenyl substituents. the reactions proceeded well to give the corresponding cycloadduct in good yields (entry 4 and 6 in Table 2). However the $[2+2+2]$ cycloaddition between 1.7-diphenyl-1.6-heptadiyne (1e) and crclopentadiene showed a significantly decreased catalytic reactivity (entry 5 in Table 2 ). The reaction gave only $18 \%$ of the cycloadduct $2 \mathrm{e}$ and the starting diyne $1 \mathrm{e}$ was recovered intact.

Although the precise reaction mechanism of Co-catalyzed $[2+2+2]$ cycloaddition and carbonylative [4+2] cycloaddition between internal diynes and cyclopentadiene under $\mathrm{CO}$ pressure has not been revealed yet. an explanation for variability in the reaction pathway's according to $\mathrm{CO}$ pressure may be provided from the results investigated here (Figure 2).

It is assumed that the effect of $\mathrm{CO}$ pressure on the transfomation of a cobaltacyclopentadiene intennediate $\mathbf{I}$ into each of the cycloadducts will play a major role in determining the reaction routes. If the $\mathrm{CO}$ pressure is not high enough 


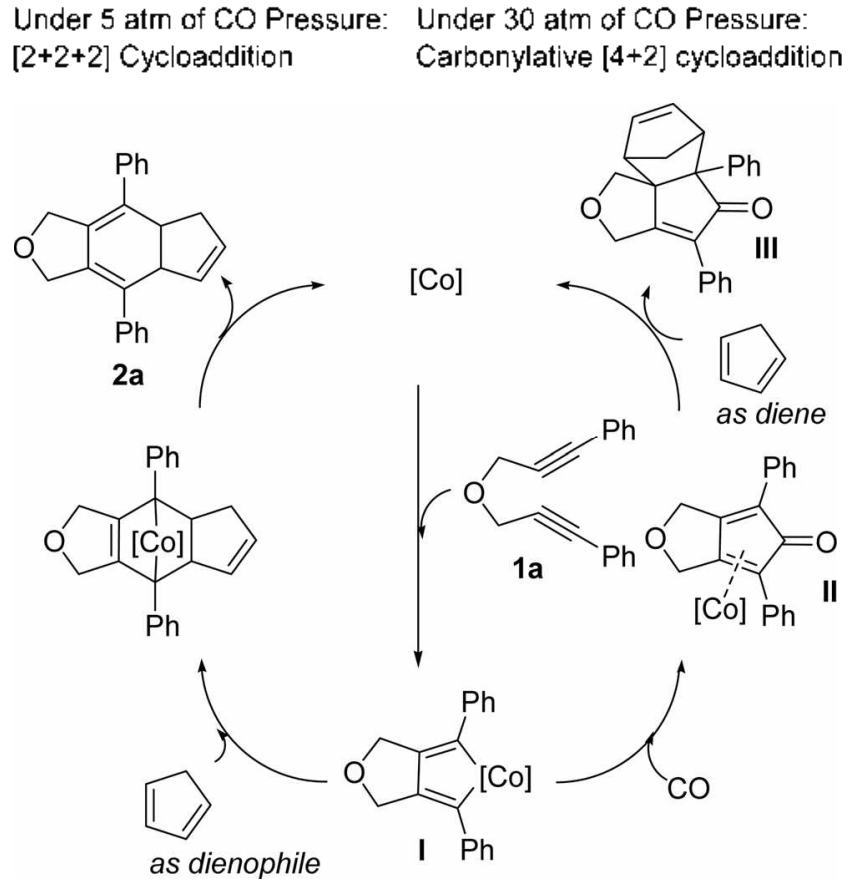

Figure 2. Reaction pathways according to $\mathrm{CO}$ pressure in $\mathrm{CO}$ catalyzed cycloaddition between intemal diynes and cyclopentadiene.

to insert carbon monoxide into the $\mathrm{Co}-\mathrm{C}$ bond of the intermediate $I$, then cobaltacyclopentadiene will act as a diene ${ }^{8}$ and participate in the cyclization with a double bond of cyclopentadiene producing the $[2+2+2]$ cycloadduct 2 a. On the contrary, the cobaltacyclopentadiene intermediate I will be transformed into a cyclopentadienone intermediate II under a high pressure of $\mathrm{CO}$, and then the intermediate II acts as a dienophile to react with cyclopentadiene in a tandem fashion producing the carbonylative [4+2] cycloadduct III.

According to the explanation of reaction pathways cyclopentadiene acted as a dienophile ${ }^{10}$ during the $[2+2+2]$ cycloaddition reaction under $5 \mathrm{~atm}$ of $\mathrm{CO}$ pressure. At this stage. it is somewhat strange that cyclopentadiene participated as a dienophile not as a diene, in the reaction conditions under 5 atm of $\mathrm{CO}$ pressure. In order to confurm whether the reaction proceeded due to a special property of cyclopentadiene was also examined reactions involving other conjugated dienes (Scheme 3 and Table 3).

Surprisingly. the $[2+2+2]$ cycloaddition was not observed at all with the 1.3-dienes tested. Instead the tandem carbon-

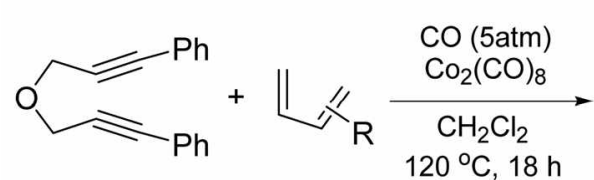

1a

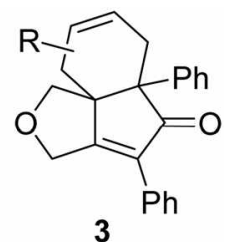

Scheme 3. $\mathrm{CO}_{2}\left(\mathrm{CO}_{8}\right.$-catalyzed tandem carbonylative [4+2] cycloaddition of the intemal divne $1 \mathrm{a}$ and conjugated dienes other than $\mathrm{CpH}$.
Table 3. $\mathrm{Co}_{2}(\mathrm{CO})_{8}-\mathrm{catalyzed}$ tandem carbonylative [4+2] cycloaddition of $1 \mathbf{a}$ and dienes"

Entry Diene Cycloaddition \begin{tabular}{lll} 
Product & Yield $(\%)^{b}$ \\
\hline
\end{tabular}

${ }^{a}$ Reactions were carried out with 1 a $(0.8 \mathrm{mmol})$. diene $(4.0 \mathrm{mmol})$, and 5 atm of CO pressure with $5 \mathrm{~mol}^{\circ}$ o of $\mathrm{CO}_{2}\left(\mathrm{CO}_{3}\right.$ in $\mathrm{CH}_{2} \mathrm{Cl}_{2}(30 \mathrm{~mL})$ for 18 h. "Isolated yield. 'Combined yield of two regioisomers with ratio of $1: 1$. The ratio was determined by a crude ${ }^{1} \mathrm{H}$ NMR spectrum.

ylative $[4+2]$ cyclization products were obtained in moderate yields. It is envisioned that $\mathrm{CO}$ insertion into the cobaltacyclopentadiene intemediate $I$ in Figure 2. which would lead to the tandem carbonylative [4+2] cyclization. could not happen easily under a low $\mathrm{CO}$ pressure. The intermediate I. which did not react as a diene either with the dienes other than cyclopentadiene in the $[2+2+2]$ cycloaddition pathway, existed for long enough to react with $\mathrm{CO}$ and was funaly transformed into the carbonylated [4+2] product. In other words, cyclopentadiene seems to have a better dienophilicity than the dienes tested in the present cyclization reaction conditions.

In summary. we have demonstrated that varying carbon monoxide pressure enables the use of cyclopentadiene as a dienophile. instead of as a diene. in the cobalt carbonylcatalyzed $[2+2+2]$ cycloaddition reaction and that the selection of the reaction route between the $[2+2+2]$ cycloaddition and the tandem carbonylative [4+2] cycloaddition can be achieved by varying pressure of carbon monoxide. Sy'ntheșis of polycyclic compounds containing 5- and 6-membered rings has been achieved by the method disclosed in this study.

\section{Experimental Section}

Solvents were dried and distilled according to standard methods before use. Dichloromethane was distilled from $\mathrm{P}_{2} \mathrm{O}_{\xi}$ under nitrogen. Reagents were purchased from Aldrich Chemical Co. and Strem Chemical Co. and were used as received. All yields are based upon isolated material. ${ }^{\mathrm{H}} \mathrm{H}$ NMR and ${ }^{13} \mathrm{C}$ NMR spectra were obtained with a Bruker $300 \mathrm{MHz}$ spectrometer. High Resolution Mass Spectra were obtained at Korea Basic Science Institute (Daegu. Korea).

Representative reaction procedures. To a $100 \mathrm{~mL}$ highpressure reactor were added bis(1-phenyl-1-propynyl) ether (1a) $(0.20 \mathrm{~g} .0 .81 \mathrm{mmol})$, cyclopentadiene $(0.33 \mathrm{~mL} .4 .05$ mmol). $30 \mathrm{~mL}$ of $\mathrm{CH}_{2} \mathrm{Cl}_{2}$, and $\mathrm{Co}_{2}(\mathrm{CO})_{8}(\mathrm{l}+\mathrm{mg} .4 \mathrm{l} \mu \mathrm{mol})$. After the solution was flushed with $\mathrm{CO}$ gas in several 
seconds. the reactor was pressurized with 5 atm of $\mathrm{CO}$. The reactor was heated at $120^{\circ} \mathrm{C}$ for $18 \mathrm{~h}$. After the reactor was cooled to room temperature and excess gas was vented, the solution was transferred into a flask and then evaporated to dryness. The residue was chromatographed on a silica gel column eluting with hexane and ethyl acetate $(\mathrm{v} / \mathrm{v}, 10: 1)$.

Compound 2a. Yield: $75 \%$ : ${ }^{1} \mathrm{H}$ NMR $\left(\mathrm{CDCl}_{3}\right): 7.49-7.36$ (m. 4H). 7.34-7.27 (m, 6H), 5.80 (m. lH). 5.67 (m. lH). 4.75 $(\mathrm{d}, J=12.7 \mathrm{~Hz} .2 \mathrm{H}), 4.53(\mathrm{t}, J=12.9 .2 \mathrm{H}) .4 .40(\mathrm{~d}, J=11.6$ $\mathrm{Hz}, \mathrm{IH}$ ). $3.9 \mathrm{l}$ (q. $J=8.8 \mathrm{~Hz}, \mathrm{IH}$ ). 2.80 (dd. $J=8.8,16.7 \mathrm{~Hz}$. $1 \mathrm{H}), 2.43(\mathrm{dd} . J=5.6 .16 .4 \mathrm{~Hz} . \mathrm{IH}) ;{ }^{13} \mathrm{C}$ NMR $\left(\mathrm{CDCl}_{3}\right)$ : 140.2. 139.7. 132.3, 132.2, 131.9. 130.2, 130.0, 129.1. 128.8. 128.6. 128.5, 128.4, 127.3, 127.1. 71.5, 48.4. 42.8. 41.3, 38.8. HRMS for $\mathrm{C}_{23} \mathrm{H}_{-} \mathrm{O}_{1}$ : calcd. 312.1514. obsd. 312.1513 .

Compound 2b. Yield: $72 \%:{ }^{~} \mathrm{H}$ NMR $\left(\mathrm{CDCl}_{3}\right): 7.18$ (brs. $8 \mathrm{H}), 5.74$ (br. $1 \mathrm{H}$ ), 5.65 (br. $1 \mathrm{H}$ ), 4.72 (d. $J=12.4 \mathrm{~Hz}, 2 \mathrm{H}$ ). $4.46(\mathrm{t}, J=12.6 .2 \mathrm{H}) .4 .35(\mathrm{~d}, J=11.3 \mathrm{~Hz} . \mathrm{lH}) .3 .87$ (q. $J=$ $8.6 \mathrm{~Hz}, \mathrm{lH}), 2.76$ (dd, $J=8.6,16.1 \mathrm{~Hz} .1 \mathrm{H}), 2.41$ (br. $\mathrm{lH}$ ). 2.36 (brs, $6 \mathrm{H}):{ }^{13} \mathrm{C} \mathrm{NMR}\left(\mathrm{CDCl}_{3}\right)$ : 137.1. 136.9, 136.6. 132.3, 131.6. 131.3, 130.0. 129.4, 129.2. 129.1, 127.0, 126.6. 71.5. $48.1,42.8,40.9,21.3$ : HRMS for $\mathrm{C}_{25} \mathrm{H}_{2} \mathrm{O}_{1}$ : calcd 340.1827. obsd. 340.1825 .

Compound 2c. Yield: 58\%: ${ }^{1} \mathrm{H}$ NMR $\left(\mathrm{CDCl}_{3}\right): 7.25$ (dd. $J$ $=4.8,9.1 \mathrm{~Hz}, 4 \mathrm{H}) .7 .10(\mathrm{t}, J=8.6 \mathrm{~Hz}, 4 \mathrm{H}) .5 .78(\mathrm{dd}, J=2.4$. $5.4 \mathrm{~Hz}, \mathrm{lH}), 5.60($ dd. $J=2.1 .5 .6 \mathrm{~Hz} . \mathrm{lH}), 4.70-4.64(\mathrm{~m}$. $2 \mathrm{H}), 4.46(\mathrm{t} . J=13 . \mathrm{l} .2 \mathrm{H}), 4.3 \mathrm{l}(\mathrm{d} . J=11.5 \mathrm{~Hz} . \mathrm{lH}) .3 .82$ $(\mathrm{m}, 1 \mathrm{H}), 2.75$ (dd. $J=8.7,16.4 \mathrm{~Hz}, \mathrm{IH}), 2.37$ (ddd, $J=2.2$. 6.7. $16.4 \mathrm{~Hz}, \mathrm{lH}) ;{ }^{13} \mathrm{C} \mathrm{NMR}\left(\mathrm{CDCl}_{3}\right): 131.9 .131 .6,130.2$. 128.8. 128.7 125.9, 115.6. 115.5, 115.3, 115.2. 71.3. 71.2 . $48.3,42.6,41.2$ : HRMS for $\mathrm{C}_{23} \mathrm{H}_{18} \mathrm{O}_{1} \mathrm{~F}_{2}$ : calcd. 348.1326 . obsd. 348.1327 .

Compound 2d. Yield: $89 \%:{ }^{~} \mathrm{H}$ NMR $\left(\mathrm{CDCl}_{3}\right): 7.59(\mathrm{~d}, J$ $=8.1 \mathrm{~Hz}, 2 \mathrm{H}) .7 .45-7.33(\mathrm{~m}, 4 \mathrm{H}), 7.32-7.22(\mathrm{~m} .+\mathrm{H}) .7 .20-$ $7.15(\mathrm{~m} .4 \mathrm{H}) .5 .70(\mathrm{~m}, \mathrm{lH}) .5 .49(\mathrm{~m}, \mathrm{lH}), 4.10(\mathrm{~m} . \mathrm{lH})$. $4.07-4.02(\mathrm{ml} .4 \mathrm{H}), 3.61$ (q, $J=8.8 \mathrm{~Hz}, \mathrm{lH}) .2 .64(\mathrm{dd}, J=$ 8.8. $16.3 \mathrm{~Hz} .1 \mathrm{H}) .2 .45$ (s, 3H). $2.27(\mathrm{~m} .1 \mathrm{H}) ;{ }^{13} \mathrm{C}$ NMR $\left(\mathrm{CDCl}_{3}\right):$ 144.1. 140.2. 139.6. 132.7. 132.1. 130.4. 130.1. 129.9. 129.5. 129.1, 128.5, 128.4. 128.1, 128.0, 127.8. 127.3, 127.1, 125.8, 52.8, 52.4, 49.0, 42.7, 41.8, 22.0: HRMS for $\mathrm{C}_{3(1} \mathrm{H}_{37} \mathrm{O}_{2} \mathrm{~N}_{1} \mathrm{~S}_{1}$ : calcd. 465.1763 , obsd 465.1762 .

Compound 2e. Yield: $18 \%:{ }^{1} \mathrm{H}$ NMR $\left(\mathrm{CDCl}_{3}\right): 7.43-7.15$ $(\mathrm{m}, \mathrm{lOH}) .5 .71(\mathrm{~m}, \mathrm{lH}) .5 .58(\mathrm{~m}, \mathrm{lH}) .4 .29(\mathrm{~d}, J=11.0 \mathrm{~Hz}$. lH). $3.79(\mathrm{q} . J=8.7 \mathrm{~Hz} .1 \mathrm{H}) .2 .70-2.49(\mathrm{~m} .4 \mathrm{H}) .2 .48-2.31$ (m. 2H). $1.84(\mathrm{~m} .1 \mathrm{H}), 1.37(\mathrm{~m} .1 \mathrm{H}) \cdot{ }^{13} \mathrm{C}$ NMR $\left(\mathrm{CDCl}_{3}\right)$ : 141.7. 141.2. 135.2, 132.9, 131.7. 130.6, 129.8, 128.4. 128.2. 128.1. 128.0, 127.8. 127.5, 126.5. 48.7, 42.8, 41.5. 32.6. 32.5. 25.4: HRMS for $\mathrm{C}_{24} \mathrm{H}_{2}$ : calcd. 310.1722 , obsd. 310.1725 .

Compound 2f. Yield: $89 \%$ : ${ }^{~} \mathrm{H}$ NMR $\left(\mathrm{CDCl}_{\hat{j}}\right): 7.42-7.30$ (m, $10 \mathrm{H}) .5 .72(\mathrm{~m}, \mathrm{lH}) .5 .53(\mathrm{~m}, \mathrm{lH}) .4 .24(\mathrm{~d}, J=11.2 \mathrm{~Hz}$. lH) $3.72(\mathrm{~m} .1 \mathrm{H}) .3 .71$ (s. $3 \mathrm{H}$ ). 3.58 (s. $3 \mathrm{H}$ ). 3.17 (dt. $J=$ $3.3 .16 .3 \mathrm{~Hz}, 2 \mathrm{H}), 3.13-3.00(\mathrm{~m} .2 \mathrm{H}) .2 .66$ (dd. $J=8.8 .16 .3$ Hz, $1 \mathrm{H}), 2.33(\mathrm{~m} .1 \mathrm{H}):{ }^{13} \mathrm{C}$ NMR $\left(\mathrm{CDCl}_{3}\right): 172.2,171.7$. 141.0. 140.4. 132.6, 132.2, 131.2. 130.9, 129.9, 129.6 . 129.2. 128.4. 128.3, 128.0. 127.9. 126.9. 58.8. 53.1. 53.0. 52.9. 48.9. 42.7. 41.8. 39.4: HRMS for $\mathrm{C}_{2 \otimes} \mathrm{H}_{\triangle 6} \mathrm{O}_{4}$ : calcd.
426.1831 , obsd. 426.1832 .

Compound 3a. Yield: 61\%: ${ }^{1} \mathrm{H}$ NMR $\left(\mathrm{CDCl}_{3}\right)$ : 7.43-7.25 $(\mathrm{m}, \mathrm{lOH}), 6.30(\mathrm{t}, J=7.5 \mathrm{~Hz} . \mathrm{lH}), 6.10(\mathrm{t}, J=7.4 \mathrm{~Hz} . \mathrm{lH})$, $4.94(\mathrm{~d}, J=16.1 \mathrm{~Hz}, 1 \mathrm{H}), 4.58(\mathrm{~d}, J=16.1 \mathrm{~Hz} .1 \mathrm{H}), 4.22(\mathrm{~d}$. $J=8.5 \mathrm{~Hz}, 1 \mathrm{H}$ ). 3.51 (d. $J=8.5 \mathrm{~Hz} .1 \mathrm{H}), 3.22$ (br s. $\mathrm{lH}$ ), 2.98 (br s. $1 \mathrm{H}), 2.07(\mathrm{~m} .2 \mathrm{H}), 1.52(\mathrm{~m}, \mathrm{lH}) .1 .29(\mathrm{~m} . \mathrm{HH})$; ${ }^{13} \mathrm{C} \mathrm{NMR}\left(\mathrm{CDCl}_{3}\right): 208.8,177.9,136.4,136.3,134.9,131.6$, 130.6. 128.7. 128.6. 128.5. 128.4. 128.2, 127.0, 70.7. 65.7. 63.0, 59.4. 39.8, 36.5. 22.4, 19.2; IR $(C=0) 1700 \mathrm{~cm}^{-1}$. HRMS for $\mathrm{C}_{25} \mathrm{H}_{22} \mathrm{O}_{2}$ : calcd. 354.1620 , obsd. 354.1617

Compound 3b. Yield: $35 \%$ : ${ }^{1} \mathrm{H}$ NMR $\left(\mathrm{CDCl}_{3}\right)$ : $7.4 \mathrm{l}$ (d, $J$ $=7.2 \mathrm{~Hz}, 2 \mathrm{H}) \cdot 7.30-7.20$ (m. 3H), $7.09-7.05(\mathrm{~m}, 3 \mathrm{H}) .6 .90$ (d. $J=7.1 \mathrm{~Hz} .2 \mathrm{H}) .4 .8 \mathrm{~L}(\mathrm{~d}, J=17.0 \mathrm{~Hz} . \mathrm{lH}) .4 .37(\mathrm{~d}, J=$ $17.0 \mathrm{~Hz}, 1 \mathrm{H}), 3.51(\mathrm{~d}, J=8.4 \mathrm{~Hz}, \mathrm{lH}) .2 .69(\mathrm{~d} . J=8.4 \mathrm{~Hz}$. lH). $2.51(\mathrm{~d}, J=15.0 \mathrm{~Hz}, \mathrm{lH}) .2 .45(\mathrm{~d} . J=14.0 \mathrm{~Hz} . \mathrm{lH})$, $2.4 \mathrm{l}(\mathrm{d}, J=13.0 \mathrm{~Hz}, \mathrm{lH}) .2 .28(\mathrm{~d}, J=15.0 \mathrm{~Hz}, \mathrm{lH}), 1.50(\mathrm{~s}$, $3 \mathrm{H}) .1 .46$ (s. $3 \mathrm{H}) ;{ }^{13} \mathrm{C}$ NMR $\left(\mathrm{CDCl}_{3}\right): 209.6 .177 .3,141.3$, $134.7,130.6,129.7 .128 .7 .128 .6,128.5,128.1 .126 .9$. $126.7,125.8,74.8,65.7,62.5,59.4,40.3,39.8,19.4,19.0$ : IR $(\mathrm{C}=\mathrm{O}) 1702 \mathrm{~cm}^{-1}$. HRMS for $\mathrm{C}_{25} \mathrm{H}_{24} \mathrm{O}_{2}$ : calcd. 356.1776 , obsd. 356.1776 .

Compound $3 c$. Two regioisomers having methyl group in different position were obtained.

$3 \mathrm{c}-1$ : Yield: $28 \%,{ }^{1} \mathrm{H}$ NMR $\left(\mathrm{CDCl}_{3}\right): 7.61($ d. $J=7.2 \mathrm{~Hz}$, $2 \mathrm{H}) .7 .43(\mathrm{~m} .3 \mathrm{H}) .7 .26(\mathrm{~m} .3 \mathrm{H}) .7 .10(\mathrm{~d}, J=7.0 \mathrm{~Hz} .2 \mathrm{H})$. $5.70($ br s, $1 \mathrm{H}) .5 .00(\mathrm{~d}, J=16.7 \mathrm{~Hz} .1 \mathrm{H}), 4.53(\mathrm{~d}, J=16.7$ Hz. $\mathrm{lH}), 3.69(\mathrm{~d} . J=9.0 \mathrm{~Hz}, \mathrm{lH}) .2 .86(\mathrm{~d} . J=8.6 \mathrm{~Hz} . \mathrm{lH})$, $2.83(\mathrm{~d} . J=8.6 \mathrm{~Hz} . \mathrm{lH}), 2.64$ (d. $J=15.1 \mathrm{~Hz}, 1 \mathrm{H}), 2.55$ (d. $J$ $=14.7 \mathrm{~Hz}, 1 \mathrm{H}) .2 .47($ d. $J=14.7 .1 \mathrm{H}), 1.70(\mathrm{~s} .3 \mathrm{H}) ;{ }^{13} \mathrm{C}$ NMR $\left(\mathrm{CDCl}_{3}\right): 210.3,177.6 .141 .6,139.6 .134 .9,130.6$. 128.8, 128.7. 128.3. 128.2. 127.0. 126.8. 119.5. 75.0, 65.7. $62.2,59.0 .38 .3 .33 .9,23.6 ; \mathrm{IR}(\mathrm{C}=\mathrm{O}) 1706 \mathrm{~cm}^{-1}$. HRMS for $\mathrm{C}_{24} \mathrm{H}_{22} \mathrm{O}_{2}$ : calcd. 342.1620 . obsd 342.1617 .

3c-2: Yield: $12 \% ;{ }^{1} \mathrm{H}$ NMR $\left(\mathrm{CDCl}_{3}\right): 7.60($ d. $J=7.2 \mathrm{~Hz}$, $2 \mathrm{H}) .7 .34$ (m. 3H). 7.19 (m. 3H), 7.09 (d. $J=7.0 \mathrm{~Hz} .2 \mathrm{H})$, 5.45 (br s, IH). $4.94(\mathrm{~d}, J=16.7 \mathrm{~Hz} .1 \mathrm{H}), 4.53(\mathrm{~d}, J=16.7$ Hz. $\mathrm{lH}), 3.67($ d. $J=9.0 \mathrm{~Hz}, \mathrm{lH}) .2 .84(\mathrm{~d}, J=8.5 \mathrm{~Hz} . \mathrm{lH})$, 2.67 (d. $J=8.5 \mathrm{~Hz}, 1 \mathrm{H}), 2.60(\mathrm{~d} . J=14.9 \mathrm{~Hz}, 1 \mathrm{H}) .2 .58$ (d. $J$ $=14.8 \mathrm{~Hz}, 1 \mathrm{H}) .2 .43(\mathrm{~d}, J=14.8 \mathrm{~Hz}, 1 \mathrm{H}), 1.73(\mathrm{~s} .3 \mathrm{H}):{ }^{13} \mathrm{C}$ NMR $\left(\mathrm{CDCl}_{2}\right): 209.5,177.8 .141 .4,135.4 .134 .5,128.8$. $128.7,128.5,128.2,128.0,126.9 .123 .0 .75 .2 .65 .8,62.5$. 58.9. 38.4 33.9. 23.2: IR $(\mathrm{C}=\mathrm{O}) 1706 \mathrm{~cm}^{-1}$. HRMS for $\mathrm{C}_{24} \mathrm{H}_{22} \mathrm{O}_{2}$ : calcd. 342.1620 . obsd 342.1618

Acknowledgements. This work was supported by the Korean Govermment (MOEHRD) (KRF-2005-070-C00072) and the SRC/ERC program of MOST/KOSEF (R11-2005065). J. W. H is grateful for the research fund of "On-Site Cooperative Agriculture Research Project (Project No. $20070201080024) *$, RDA, Republic of Korea.

\section{References}

1. (a) Petit. M: Aubert. C.: Malacria. M. Org. Lett. 2004. 6. 3937 : (b) Bonaga. L. V. R.: Zhang. H. C.: Maryanoff. B. E. Chent. Conmun. 2004. 2394; (c) Gandon, V.: Leca, D: Aechtner. T: Vollhardt. K. P. C.: Malacria. M: Aubert. C. Org. Lett. 2004, 6. 3405: (d) Chouracui, G.: Petit. M.: Aubert. C.: Malacria, M. Org. 
Lett. 2004. 6. 1519: (e) Gutnov. A.: Heller. B.: Fischer. C: Drexler. H. J.: Spannenberg. A.: Sundermann. B.: Sundermann. C. Angew. Chen. Int. Ed. 2004. 43. 3795: (f) Bonaga. L. V. R: Zhang. H. C.: Gauthier. D. A.: Reddy. I.; Maryanoff. B. E. Org. Lett. 2003, 5. 4537: (g) Varela. J. A: Sa, C. Chem. Rev 2003. 103, 3787: (h) Hilt, G.: Smolko, K. I. Angew. Chem. Mt. Ed. 2003. 42.2795 .

2. (a) Han. S.: Anderson. D. R.: Bond. A. D.: Chu. H. V:: Disch. R. L.: Holmes. D.: Schulman. J. M.: Teat. S. J.: Vollhardt. K. P. C.: Whitener, G. D. Angew: Chem. Int Ed 2002, H1, 3227; (b) Pelissier, H.: Rodriguez. I.: Vollhardt. K. P. C. Chem. Eur. J. 1999. 5. 3549; (c) Cammack. J. K. Jalisatgi, S: Matzger. A. J.: Negron, A.: Vollhardt. K. P. C. J. Org Chent 1996. 61. 4798: (d) Vollhardt. K. P. C. Angew. Chem. 1984. 96. 525: (e) Vollhardt. K. P. C. Acc. Chent Res. 1977. 10. 1.

3. (a) Eichberg, M. J.: Dorta, R. L.: Grotjahn, D. B.: Lamottke, K.: Schmidt M. Vollhardt K. P. C. J. Am. Chem. Soc. $2001,123$. 9324: (b) Saa. C.: Crotts. D. D.: Hsu, G. Vollhardt. K. P. C. Sintent 1994. 487: (c) Lecker. S. H.: Nguyen. N. H.: Vollhardt. K. P. C. J. Ant Chem Soc. 1986, 108. 856: (d) Dunach. E: Halterman. R. L.: Vollhardt. K. P. C. J. An. Chem. Soc. 1985. 107, 1664.

4. (a) Sheppard. G. S.: Vollhardt. K. P. C. J. Org. Chem. 1986. 51.
5496: (b) Boese. R.: Knölker. H. J.: Vollhardt. K. P. C. Angew: Chent. Int Ed Engt 1987. 26. 1035: (c) Boese. R.: Harvey. D. F.: Malaski. M. T.: Vollhardt. K. P. C. J. Ant Chent. Soc. 1994. 116. 11153; (d) Perez, D.; Siesel, B. A.; Malaska, M. J; David, E.: Vollhardt. K. P. C. Symlett 2000. 366; (e) Pelissier, H.; Rodriguez. J.: Vollhardt. K. P. C. Chem Em: J. 1999. 5. 3549

5. For titaniumn-mediated $[2+2+2]$ coupling. see: Sung. M. J.: Pang. J. H.: Park. S. B.: Cha. J. K. Org. Lett. 2003. 5.2137.

6. (a) Sont. S. U.: Park. K. H.: Lee. S. T.: Kiml. B. M.: Chung. Y. K Synlett 2003. 1101; (b) Kim. D. H.; Son. S. U; Chung. Y. K Chem Commun 2002. 56: (c) Son. S. U.; Yoon. Y. A.; Choi. D S.; Park, J. K.: Kim, B. M.: Chung, Y. K. Org. Lett. 2001, 3. 1065 ; (d) Son. S. U.: Chung. Y. K.: Lee. S. G. J. Org. Chem. 2000. 65. 6142 .

7. Kim. D. H.: Chung. Y. K.: Han. J. W. Bull. Korean Chem. Soc. 2007. 28, 1089.

8. Wakatsuli. Y: Kuramitsu, T.: Yamazaki. H. Tetrahedron Lett. $1974.52,4549$

9. Wakatsuki. Y.: Yamazaki. H. J. Organontet. Chem. 1977. 139. 169 .

10. (a) Lawson. K. R.: Singleton. A.: Whitham. G. H. J. Chent. Soc. Perkin Trans. I 1984, 865: (b) Tedder, J. M.: Horspool. W. M. Smith. P. I. J. Chem. Soc. C 1971, 1638. 